\title{
Saccharum angustifolium (Nees) Trin. (Poales: Poaceae) as hibernacle for stink bugs during the soybean and corn off-season in Southern Brazil
}

\author{
Saccharum angustifolium (Nees) Trin. (Poales: Poaceae) como hibernáculo \\ para percevejos durante a entressafra de soja e milho no sul do Brasil
}

\author{
Eduardo Engel ${ }^{1 *}$ (D), Mauricio Paulo Batistella Pasini ${ }^{2}$ (D), José Luiz Tragnago ${ }^{2}$ (D), \\ Daniele Caroline Hörz' ${ }^{1}$, Nadiel Augusto Kist ${ }^{2}$ (D), João Fernando Zamberlan' ${ }^{1}$, \\ Rafael Pivotto Bortolotto'
}

\begin{abstract}
Host plants are key factors in the survival of true bugs during unfavorable periods. The objective of this study was to evaluate the composition, diversity and abundance of pentatomid bugs in Saccharum angustifolium (Nees) Trin. (Poales: Poaceae). Plants were evaluated during the soybean and corn off-season for five years. A total of 250 plants were sampled, the true bug population was counted and used for statistical and faunistic analysis. We observed the occurrence of the species: Euschistus heros (F.), Dichelops furcatus (F.), Dichelops melacanthus (Dallas), Edessa meditabunda (F.), and Edessa ruformaginata (De Geer). Among the species, the highest population density was verified for $E$. meditabunda, E. heros, and D. furcatus. We also observed a direct effect of the clump diameter on the population density of $E$. heros, D. furcatus, and E. meditabunda. Finally, we conclude that $S$. angustifolium plants serve as adequate hibernacles for the survival of true bugs of economic importance during the soybean and corn off-season.
\end{abstract}

KEYWORDS: associated plant; survivor; quiescence; insect-pest; host.
RESUMO: Plantas hospedeiras são fatores fundamentais na sobrevivência de percevejos durante períodos desfavoráveis. O objetivo deste trabalho foi avaliar a composiçáo, diversidade e abundância de espécies de percevejos pentatomídeos ocorrentes em plantas de Saccharum angustifolium (Nees) Trin (Poales: Poaceae). As plantas foram avaliadas durante a entressafra de soja e milho por cinco anos. Foram amostradas 250 plantas, sendo a populaçáo de percevejos contabilizada e utilizada para a análise estatística e faunística. Observamos a ocorrência das espécies: Euschistus heros (F.), Dichelops furcatus (F.), Dichelops melacanthus (Dallas), Edessa meditabunda (F.) e Edessa ruformaginata (De Geer). Entre as espécies, foi verificada uma maior densidade populacional para E. meditabunda, E. heros e D. furcatus. Observamos, também, o efeito direto do diâmetro de touceira sobre a densidade populacional de $E$. heros, D. furcatus e E. meditabunda. Por fim, concluímos que plantas de $S$. angustifolium servem como hibernáculos adequados para a sobrevivência de percevejos de importância econômica durante a entressafra de soja e milho.

PALAVRAS-CHAVE: planta associada; sobrevivência, quiescência, inseto-praga, hospedeiro. 


\section{INTRODUCTION}

Pentatomid bugs are among the major entomological problems in various regions of the world. Due to their feeding behavior these insects cause significant damage to most large crops in Brazil (soybean, corn and wheat) (McPHERSON, 2018). In addition to the direct losses caused in soybean, corn and wheat, phytophagous pentatomid bugs can cause indirect losses, mainly to soybean, causing reduction in germination potential and seed vigor (PANIZZI et al., 2012).

Given the economic importance of these insects, we must understand their behavior during the off-season. Several papers highlight wild plants associated with the survival of true bugs in different agroecosystems; these insects seek shelters to hibernate during periods of low temperatures and food shortages (KLEIN et al., 2013; SMANIOTTO; PANIZZI, 2015; PASINI et al., 2018).

In Brazil, the occurrence of plants in areas surrounding the cultivation is related to the accumulation of true bug populations during the off-season. These plants provide adequate shelter and microclimate for the survival of these insects, which keep waiting for the return of favorable conditions. In this way, the plants associated with these organisms become sources of reinfestation of cultivated areas (PANIZZI, 1997; KLEIN et al., 2013; SMANIOTTO; PANIZZI, 2015; PASINI et al., 2018).

In this context, the study objective was to identify the diversity, abundance, and community structure of phytophagous pentatomid bugs during soybean and corn off-season in Saccharum angustifolium (Nees) Trin (Poales: Poaceae), which are present in the surroundings of cultivated area for five years.

\section{MATERIAL AND METHODS}

The study was carried out in the municipality of Cruz Alta, state of Rio Grande do Sul, during the soybean and corn offseasons, between 2014 and 2018. The climate of the study area, according to Köppen and Geier, belongs to the Cfa type (KUINCHTNER; BURIOL, 2001). During the study period, $S$. angustifolium plants with different clump diameters were sampled. For each diameter $(10,20,30,40$, and $50 \mathrm{~cm})$, ten plants were sampled with a minimum distance of 15 meters between plants and a maximum of 20 meters from the crop border. Each plant was considered an experimental unit, totaling 250 experimental units at the end of the experiment. The number of true bugs obtained in these plants was used for statistical analysis.

To verify the normality of data and homogeneity of variances, the Anderson-Darling and Bartlett tests were used, respectively. For data that did not meet the assumptions, they were submitted to the function $\sqrt{x+0.5}$. After normalization, data were submitted to analysis of variance (ANOVA), and the averages between the species of true bugs and between the years were compared with the Scott-Knott test at 5\% probability of error.

For the relation between clump diameters and population density, data were subjected to ANOVA; when significant $(\mathrm{p}<0.05)$, linear regression analysis was performed between clump density and clump diameter. For all analyzes, the program R v.3.0.3 was used (R CORE TEAM, 2016).

Quantitative data were analyzed with the alpha diversity (diversity and distribution of species abundance - SAD). The suitability of SAD was tested in four models: geometric, broken-stick, log-series, and log-normal. The sampling sufficiency curve for the abundance of $S$. angustifolium-associated pentatomids was obtained with 999 randomizations and compared with the non-parametric richness estimators Chao 1, Chao 2, Jackknife 1, and Jacknife 2 to determine the sampling efficiency, according to the methodology used by BIANCHI et al. (2019). Each richness estimator considers a different parameter, that is, the occurrence of singletons, doubletons, unique, and duplicates. To verify the similarity and distance of true bug species, we used the Morisita and Jaccard indices, respectively. All analyses were performed using the software PASt 3.34 (HAMMER et al., 2001).

\section{RESULTS AND DISCUSSION}

At the end of the experiment, we observed a total of 3,555 pentatomid bugs distributed in six species (Table 1). We observed a higher frequency for Edessa meditabunda (F.), with 43\%, followed by Euschistus heros (F.), 32\%, and Dichelops furcatus (F.), 22\% (Table 1).

Among the species, during the same year of evaluation, we observed low variability in abundance distribution. From 2014 to 2017, we observed a higher population density of the species E. meditabunda, in 2014 and 2015, followed by $D$. furcatus; in 2016 and 2017, it was E. heros. Only for 2018 did we observe that $E$. heros had a population statistically similar to E. meditabunda (Table 2).

Table 1. Composition, abundance (N), and frequency (F) of true bug (Pentatomidae) sampled in Saccharum angustifolium (Poales: Poacae) over soybean and corn off-season, from 2014 to 2018, in Cruz Alta City, Rio Grande do Sul state, Brazil.

\begin{tabular}{lcc|} 
Species & $\mathbf{n}$ & $\mathbf{F}(\%)$ \\
\hline Euschistus heros (F.) & 1,139 & $32 \%$ \\
\hline Dichelops furcatus (F.) & 791 & $22 \%$ \\
\hline Dichelops melacanthus (Dallas) & 6 & $0 \%$ \\
\hline Edessa meditabunda (F.) & 1,532 & $43 \%$ \\
\hline Edessa ruformaginata (De Geer) & 87 & $2 \%$ \\
\hline Total & 3,555 & 100 \\
\hline
\end{tabular}


Table 2. Statistical parameters of the true bug population in Saccharum angustifolium (Nees) Trin. (Poales: Poaceae) during soybean and corn off-season. Cruz Alta City, from 2014 to 2018.

\begin{tabular}{|c|c|c|c|c|c|}
\hline & Eh & $D f$ & Dm & $\mathrm{Em}$ & Er \\
\hline \multicolumn{6}{|l|}{2014} \\
\hline Sum & 24 & 58 & 1 & 110 & 3 \\
\hline Average & $0.48 c$ & $1.16 b$ & $0.02 d$ & $2.20 a$ & $0.06 d$ \\
\hline Maximum & 3 & 6 & 1 & 8 & 1 \\
\hline Minimum & 0 & 0 & 0 & 0 & 0 \\
\hline Variance & 0.58 & 2.26 & 0.02 & 5.35 & 0.06 \\
\hline Standard deviation & 0.76 & 1.50 & 0.14 & 2.31 & 0.24 \\
\hline Cv & 1.59 & 1.30 & 7.07 & 1.05 & 4.00 \\
\hline \multicolumn{6}{|l|}{2015} \\
\hline Sum & 230 & 237 & - & 260 & 18 \\
\hline Average & $4.60 c$ & $4.74 b$ & - & $5.20 a$ & $0.36 d$ \\
\hline Maximum & 11 & 14 & - & 12 & 4 \\
\hline Minimum & 0 & 0 & - & 0 & 0 \\
\hline Variance & 11.96 & 14.73 & - & 13.63 & 0.93 \\
\hline Standard deviation & 3.46 & 3.84 & - & 3.69 & 0.96 \\
\hline Cv & 0.75 & 0.81 & - & 0.71 & 2.68 \\
\hline \multicolumn{6}{|l|}{2016} \\
\hline Sum & 314 & 198 & - & 552 & 23 \\
\hline Average & $6.28 b$ & $3.96 c$ & - & $11.04 a$ & $0.46 d$ \\
\hline Maximum & 23 & 9 & - & 42 & 4 \\
\hline Minimum & 0 & 0 & - & 0 & 0 \\
\hline Variance & 33.68 & 9.63 & - & 120.53 & 0.74 \\
\hline Standard deviation & 5.80 & 3.10 & - & 10.98 & 0.86 \\
\hline $\mathrm{Cv}$ & 0.92 & 0.78 & - & 0.99 & 1.87 \\
\hline \multicolumn{6}{|l|}{2017} \\
\hline Sum & 311 & 162 & - & 361 & 28 \\
\hline Average & $6.22 b$ & $3.24 c$ & - & $7.22 a$ & $0.56 d$ \\
\hline Maximum & 13 & 9 & - & 33 & 6 \\
\hline Minimum & 0 & 0 & - & 0 & 0 \\
\hline Variance & 15.32 & 6.10 & - & 52.34 & 1.48 \\
\hline Standard deviation & 3.91 & 2.47 & - & 7.23 & 1.21 \\
\hline $\mathrm{Cv}$ & 0.63 & 0.76 & - & 1.00 & 2.17 \\
\hline \multicolumn{6}{|l|}{2018} \\
\hline Sum & 264 & 138 & 5 & 252 & 15 \\
\hline Average & $5.28 a$ & $2.76 b$ & $0.10 c$ & $5.04 a$ & $0.30 c$ \\
\hline Maximum & 12 & 8 & 1 & 12 & 2 \\
\hline Minimum & 0 & 0 & 0 & 0 & 0 \\
\hline Variance & 14.29 & 4.72 & 0.09 & 13.02 & 0.30 \\
\hline Standard deviation & 3.78 & 2.17 & 0.30 & 3.61 & 0.54 \\
\hline $\mathrm{Cv}$ & 0.72 & 0.79 & 3.03 & 0.72 & 1.81 \\
\hline
\end{tabular}

*Means followed by different letters in the line differ statistically with the Scott-Knott test at $5 \%$ probability. Eh (Euschistus heros), Df (Dichelops furcatus), Dm (Dichelops melacanthus), Em (Edessa meditabunda), and Er (Edessa ruformaginata). 
The importance of knowledge of populations occurring in associated host plants in the off-season of crops is related to the ability to predict the emergence of harmful species to cultivated plants (LINK; GRAZIA, 1987). KLEIN et al. (2013) found true bugs of economic importance sheltering in plants of Andropogon bicornis L. (Poales: Poaceae), during the off-season. Several authors highlight this behavior presented by true bugs, that, when seeking shelter in associated host plants,survive, ensuring the reinfestation of the area in the next crop (MEDEIROS; MEGIER, 2009; KLEIN et al., 2013; PASINI et al., 2015, 2018).

D. melacanthus was recorded only in the 2014 and 2018 off-season, and with a low population density (Table 2). Studies show that this true bug has a greater distribution in the Southeast and Midwest of Brazil, and that the Southern region is more restricted to $D$. furcatus (PANIZZI et al., 2012).

Among the sampled species, we found that at least three (E. heros, D. furcatus and D. melacanthus) are economically important for soybean and corn crops. In general, E. meditabunda had the highest population density over the five years, followed by $E$. heros and $D$. furcatus (Fig. 1).

We also observed that the true bugs of the species E. meditabunda presented high population density for some plants, increasing the general average. This may be a result of the level of aggregation that this species has; however, it may also be influenced by food preference. Brown-winged stink bug $E$. meditabunda has different food preferences than the others sampled (except for E. ruformaginata); this species is characterized by preferring vegetative parts of plants, such

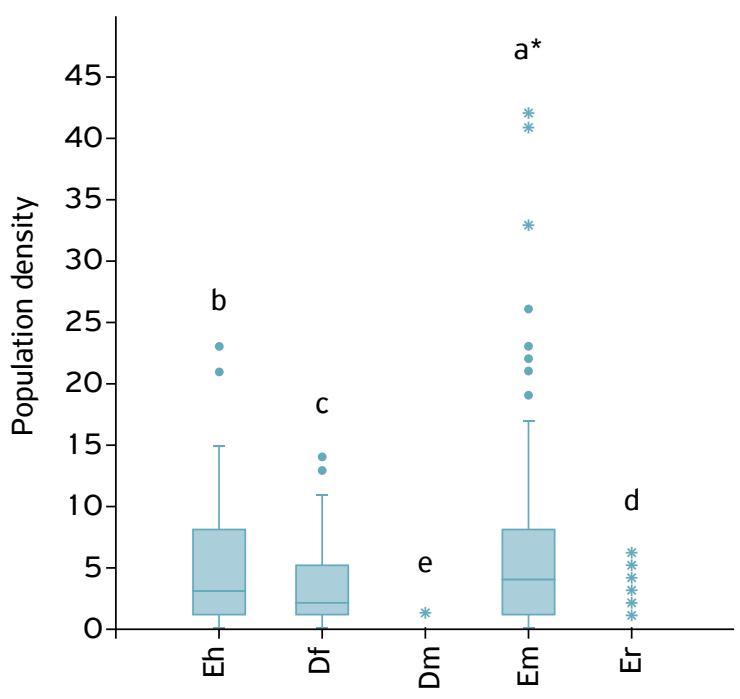

*Letters differ statistically with the Scott-Knott test at 5\% probability. Eh (Euschistus heros), Df (Dichelops furcatus), Dm (Dichelops melacanthus), Em (Edessa meditabunda), and Er (Edessa ruformaginata).

Figure 1. Population density of pentatomid bugs in Saccharum angustifolium (Nees) Trin. (Poales: Poaceae) during soybean and corn off-season. Cruz Alta City, Rio Grande do Sul state, Brazil, from 2014 to 2018. as stem, branches and leaves, which increases the number of hosts in which this species is able to survive compared to the other bed bug species sampled (PANIZZI et al., 2012; HUSCH et al., 2014).

From the analysis of distribution of abundances, we found that the geometric model obtained significance $(\mathrm{k}=0.7748$; chi-square $=258.0 ; p=0.00<0.05$ ) (Fig. 2). From the rarefaction curve, we can highlight sufficiency in the sampling of true bug species from sample number 113, where the curve stabilized, indicating no occurrence of new species (Fig. 3), seen with estimators Chao 2, Jackniffe 1, Jackniffe 2, and Bootstrap. We also obtained the same number of species, as observed.

The low diversity of species is due to the continuous crop succession system (soybean-corn for five years), where the fittest are more abundant, whereas the species with the least adaptation tend to migrate or are unable to establish in this system. Studies indicate that cropping systems with crop succession, rather than rotation, tend to accumulate certain herbivorous insect species to the detriment of others (ENGEL et al., 2019).

When evaluating the tussock sizes that $S$. angustifolium formed in the landscape, we observed a significant influence of this parameter on the population density of $E$. heros $(\mathrm{F}=734.87 ; \mathrm{p}=4 \mathrm{E}-100<0.05)$, E. meditabunda $(\mathrm{F}=570.77$; $\mathrm{p}=1.3 \mathrm{E}-84<0.05)$, and D. furcatus $(\mathrm{F}=859.14 ; \mathrm{p}=2 \mathrm{E}-110$ $<0.05)$, resulting in a direct effect on increasing population density as a function of increasing plant diameter (Fig. 4).

PASINI et al. (2018), when studying Tibraca limbativentris Stal. (Hemiptera: Pentatomidae), found the same behavior in plants of A. bicornis and A. lateralis. DENNIS et al. (1994)

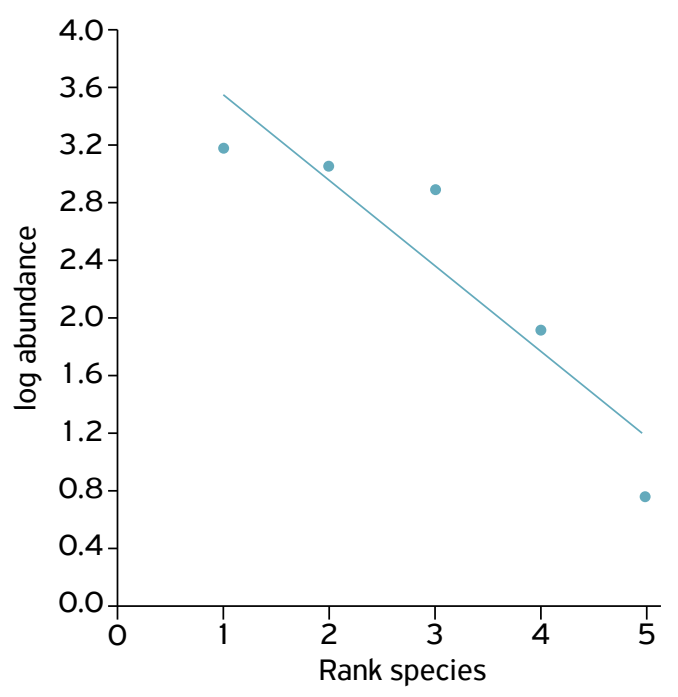

Figure 2. Distribution of abundances of pentatomid bugs in soybean and corn off-season, from 2014 to 2018, in Saccharum angustifolium Nees. (Poales: Poaceae) from the geometric model. Cruz Alta City, Rio Grande do Sul state, Brazil. 
indicate that this behavior is linked to the microclimate that plants with higher mass volume form inside clumps, providing better quiescence or hibernation conditions. KLEIN et al. (2013) present the smallest dispute for physical space, because of the greater presence of these individuals in larger plants. Plants with higher structural complexities tend to offer higher chances of survival for insects, thus sheltering a larger number of species and population abundance during unfavorable periods, becoming sources of reinfestation (HOWE; JANDER, 2008).

When comparing the final populations obtained, we found a strong similarity between the species E. meditabunda, E. heros and D. furcatus. On the other hand, the Jaccard distance index indicated disconnected populations of this group for E. ruformaginata and D. melacanthus, thus indicating adaptation of the first three species to the soybean-corn system for using $S$. angustifolium plants as a shelter during the off-season crops (Fig. 5).

The true bugs E. ruformaginata are known to be present in native vegetation areas; therefore, their occurrence is not linked to existing crops in the cultivation area, but to the type of vegetation seen in the transects between forest and cultivation areas (SILVA et al., 2006; SILVA; OLIVEIRA, 2010).

For the D. melacanthus, despite its low population density, it is considered a key-pest of corn, especially during the early development of the crop. Thus, its occurrence should be monitored in cultivated areas (PANIZZI et al., 2012). SILVA et al. (2013) observed the use of uncultivated host plants of different species for $D$. melacanthus, which were occupied during the off-season.
Despite the constant occurrence during the five years of evaluation of the species E. meditabunda, E. heros, and $D$. furcatus, we did not find the presence of nymphs or eggs of these true bugs, characterizing this plant as a non-reproductive host, serving only as a hibernacle and source of adult reinfestation of these species.

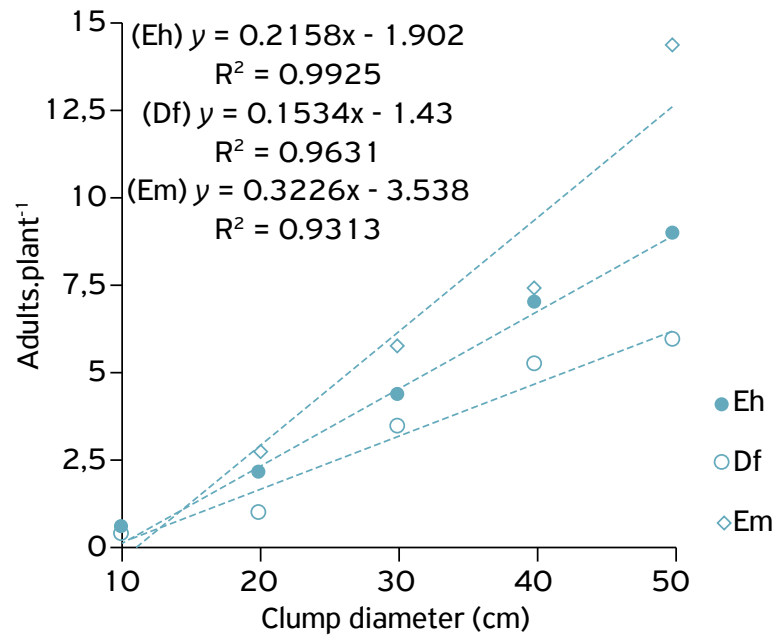

Figure 4. Regression analysis of true bug population as a function of clump diameter at Saccharum angustifolium (Nees) Trin. (Poales: Poaceae). Cruz Alta City, Rio Grande do Sul state, Brazil, from 2014 to 2018. Em (Edessa meditabunda), Eh (Euschistus heros), and Df (Dichelops furcatus).

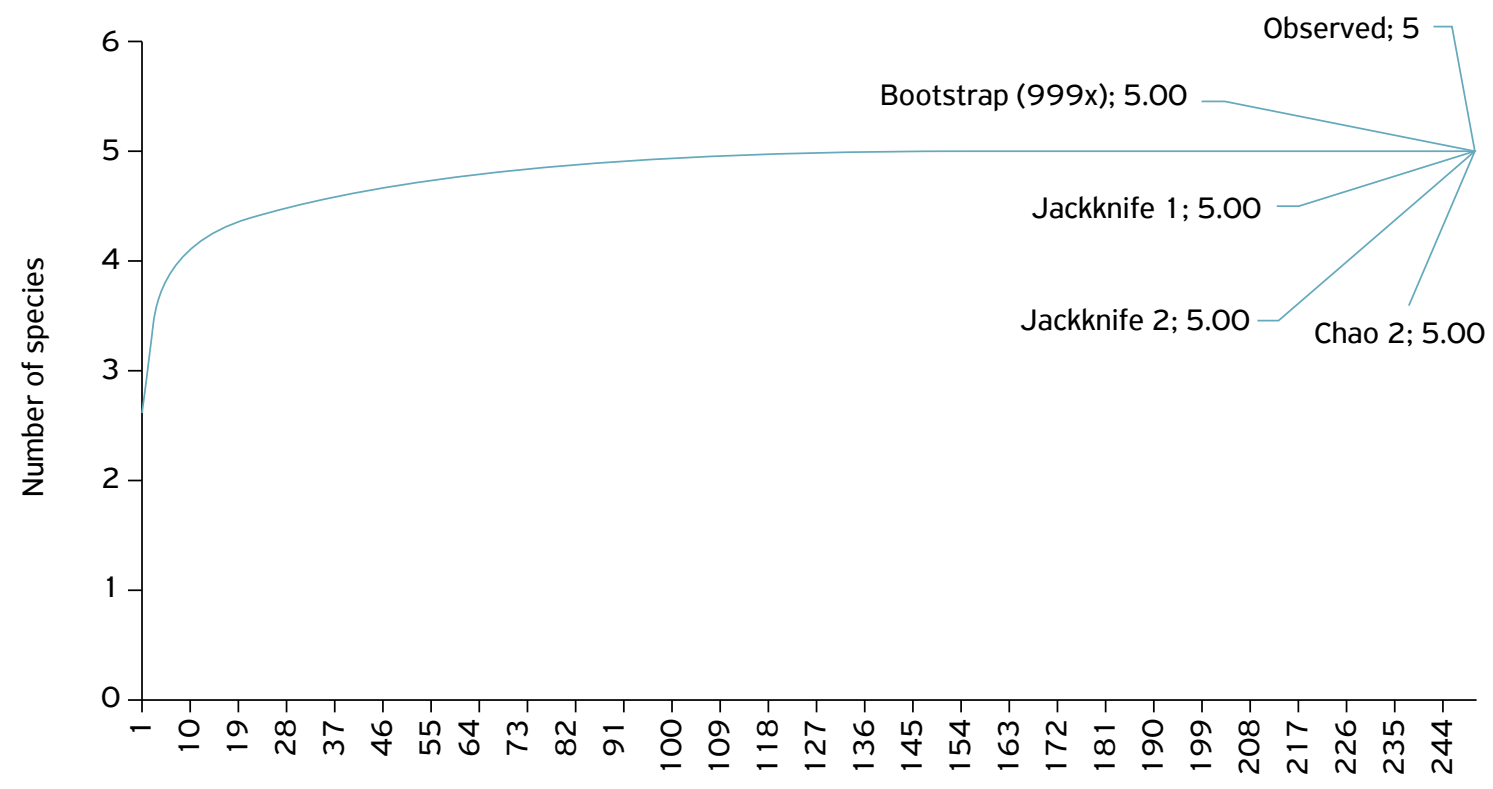

Acumulated samples

Figure 3. Rarefaction curve and species richness estimators for pentatomid bugs sampled in Saccharum angustifolium (Nees) Trin. (Poales: Poaceae) during the soybean and corn off-season, from 2014 to 2018 . Cruz Alta City, Rio Grande do Sul state, Brazil. 
Morisita

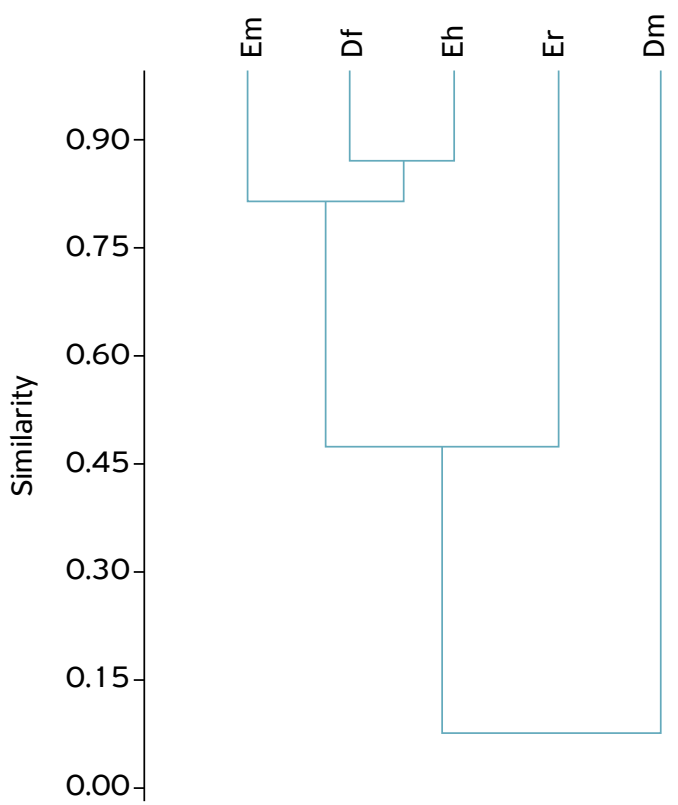

Jaccard

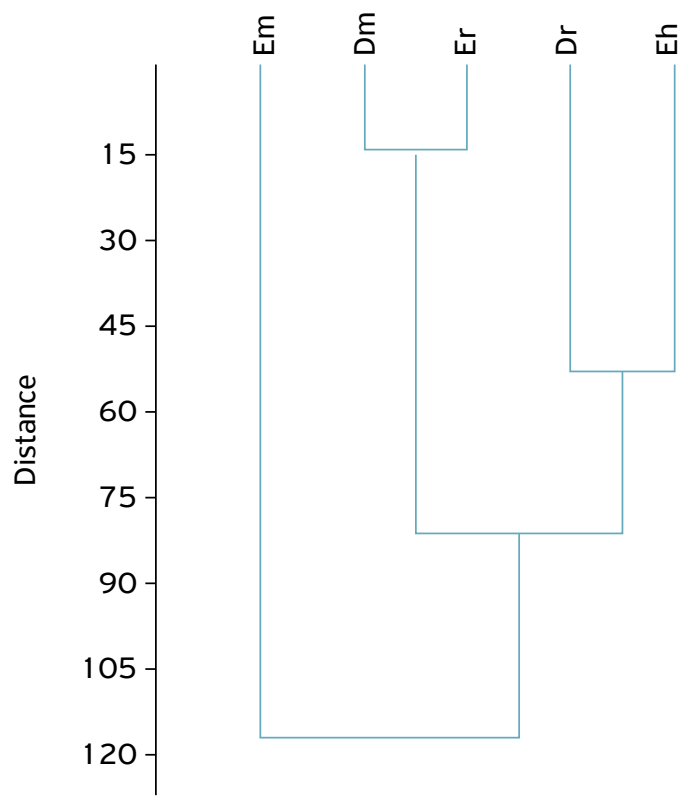

Figure 5. Dendogram of similarity and distance between species sampled in Saccharum angustifolium (Nees) Trin. (Poales: Poaceae) during soybean and corn off-season by Morisita and Jaccard indices, respectively. Cruz Alta City, Rio Grande do Sul state, Brazil, from 2014 to 2018. Eh (Euschistus heros), Df (Dichelops furcatus), Dm (Dichelops melacanthus), Em (Edessa meditabunda), and Er (Edessa ruformaginata).

\section{CONCLUSIONS}

The true bugs Edessa meditabunda, Euschistus heros, Dichelops furcatus, Dichelops melacanthus, and Edessa ruformaginata were identified.
Saccharum angustifolium is considered an economically important true bug hibernacle during soybean and corn off-season. Its clump diameter directly influences the population density of E. meditabunda, E. heros, and D. furcatus.

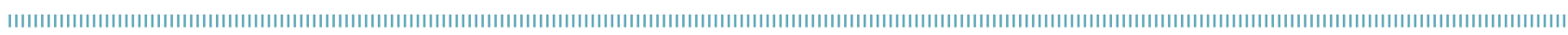

\section{REFERENCES}

BIANCHI, F.M.; MARSARO JUNIOR, A.L.; GRAZIA, J.; PEREIRA, P.R.V.S.; PANIZZI, A.R. Diversity of stink bugs (Pentatomidae) associated with Canola: Looking for potential pests. Neotropical Entomology, v.48, n.2, p.219-224, 2019. http://dx.doi. org/10.1007/s 13744-018-0642-3

DENNIS, P.; THOMAS, M.B.; SOTHERTON, N.W. Structural features of field boundaries which influence the overwintering densities of beneficial arthropod predators. Journal Applied Ecology, v.31, n.2, p.361-370, 1994. http://dx.doi.org/10.2307/2404550

ENGEL, E.; DALLA NORA, S.L.; PASINI, M.P.B.; HÖRZ, D.C. Attractive food in the sampling and seasonality of insects in soybean-oats succession. Amazonian Journal of Agricultural and Environmental Sciences, v.62, p.1-6, 2019. http://dx.doi.org/10.22491/ rca.2019.2916

HAMMER, Ø.; HARPISTA, D.A.T.; RYAN, P.D. PAST: pacote de software de estatísticas paleontológicas para educação e análise de dados. Paleontologia Electronica, v.4, p.1-9, 2001.
HOWE, G.A.; JANDER, G. Plant Immunity to insect herbivores. Annual Review of Plant Biology, v.59, p.41-66, 2008. http:// dx.doi.org/10.1146/annurev.arplant.59.032607.092825

HUSCH,P.E;;DEOLIVEIRA, M.C.N.; SOSA-GÓMEZ, D.R. Characterization of Injury Caused by Edessa meditabunda (F.), Chinavia impicticornis (Stål), and Piezodorus guildinii (West.) (Hemiptera: Pentatomidae) to Soybean. Neotropical Entomology, v.43, n.3, p.276-281, 2014. https://doi.org/10.1007/s13744-014-0209-x

KLEIN, J.T.; REDAELLI, L.R.; BARCELLOS, A. Andropogon bicornis (Poales, Poaceae): a hibernation site for pentatomoidea (Hemiptera: Heteroptera) in a rice-growing region of Southern Brazil. Neotropical Entomology, v.42, n.3, p.240-245, 2013. https://doi.org/10.1007/s13744-013-0116-6

KUINCHTNER, A.; BURIOL, G.A. Clima do Estado do Rio Grande do Sul segundo a classificação climática de Köppen e Thornthwaite. Disciplinarum Scientia, Série Naturais e Tecnológicas, Santa Maria, v.2, n.1, p.171-182, 2001 
LINK, D.; GRAZIA, J. Pentatomídeos da região central do Rio Grande do Sul (Heteroptera). Anais da Sociedade Entomológica do Brasil, v.16, p.115-129, 1987.

MCPHERSON, J.E. (Ed.). Invasive stink bugs and related species (Pentatomoidea). Biology, higher systematics, semiochemistry, and management. Boca Raton, FL: CRC Press, 2018.

MEDEIROS, L.; MEGIER, G.A. Ocorrência e desempenho de Euschistus heros (F.) (Heteroptera: Pentatomidae) em plantas hospedeiras alternativas no Rio Grande do Sul. Neotropical Entomology, v.38, n.4, p.459-463, 2009. http://dx.doi.org/10.1590/ S1519-566X2009000400003

PANIZZI, A.R. Wild hosts of pentatomids: ecological significance and role in their pest status on crops. Annual Review Entomology, v.42, p.99-122, 1997.

PANIZZI, A.R.; BUENO, A.F.; SILVA, F.A.C. Insetos que atacam vagens e grãos. In: HOFFMANN-CAMPO, C.B.; CORRÊAFERREIRA, B.S.; MOSCARDI, F. (Eds.). Soja: manejo integrado de insetos e outros artrópodes-praga. Brasília: Embrapa, 2012. p.335-420.

PASINI, M.P.B.; LÚCIO, A.D.C.; RIBEIRO, A.D.P. Populations of phytophagous bugs influenced by crop background and wild plants. Amazonian Journal of Agricultural and Environmental Sciences, v.58, n.4, p.410-417, 2015 . http://dx.doi. org/10.4322/rca. 1848
PASINI, M.P.B.; LÚCIO, A.D.C.; CARGNELUTTI FILHO, A.; RIBEIRO, A. L. P.; ZAMBERLAN, J. F.; LOPES, S. J. Population density of Tibraca limbativentris on flood irrigated rice and alternative host plants. Pesquisa Agropecuária Brasileira, Brasília, v.53, n.3, p.265-278, 2018. http://dx.doi.org/10.1590/s0100-204x2018000300001

R CORE TEAM. R: A language and environment for statistical computing. Vienna, Austria: RFoundation for Statistical Computing, 2016. Available from: https://www.R-project.org/. Access on: Nov. 202017.

SMANIOTTO, L.F.; PANIZZI, A.R. Interactions of selected species of stink bugs (Hemiptera: Heteroptera: Pentatomidae) from leguminous crops with plants in the Neotropics. The Florida Entomologist, v.98, n. 1, p.7-17, 2015. http://dx.doi.org/10.1653/024.098.0103

SILVA, D.P.; OLIVEIRA, P.S. Field biology of Edessa rufomarginata (Hemiptera: Pentatomidae): phenology, behavior, and patterns of host plant use. Environmental Entomology, v.39, n.6, p.19031910, 2010. https://doi.org/10.1603/EN10129

SILVA, E.J.E.; FERNANDES, J.A.M.; GRAZIA, J. Caracterização do grupo Edessa rufomarginata e descrição de sete novas espécies (Heteroptera, Pentatomidae, Edessinae). Iheringia, Série Zoologia, Porto Alegre, v.96, n.3, p.345-362, 2006. http://dx.doi. org/10.1590/S0073-47212006000300012

SILVA, J.J.; VENTURA, M.U.; SILVA, F.A.C.; PANIZZI, A.R. Population dynamics of Dichelops melacanthus (Dallas) (Heteroptera: Pentatomidae) on host plants. Neotropical Entomology, v.42, n.2, p. 141-145, 2013. https://doi.org/10.1007/s13744-012-0104-2 